\title{
Performance of vegetatively propagated Larix decidua, $L$ kaempferi and $L$ laricina hybrids
}

\author{
LE Pâques \\ INRA, Centre d'Orléans, Station d'Amélioration des Arbres Forestiers, 45160 Ardon, France
}

(Received 25 January 1991; accepted 17 October 1991)

\begin{abstract}
Summary - Interspecific hybridization between the tamarack and the Japanese and European larches was attempted. Successful crosses between the tamarack and the Japanese larch as well as the 3-way hybrid (tamarack crossed to European $x$ Japanese larches) were obtained for the first time in France but on a limited scale. Hybridization with tamarack seems possible but rather difficult due to differences in phenology and reproduction potential. Hybrid clones were successfully propagated by stem cuttings with high rates of rooting and a good quality of the root system, especially for the tamarack and its hybrids. Field performances at 8 years reveal that even if their initial growth is vigorous is absolute terms, neither the tamarack nor its hybrids could compete with the hybrid Larix decidua $\times L$ kaempferi for both growth and stem form. One exception is the 3-way hybrid $L$ laricina $x$ ( $L$ decidua $\times$ L kaempferi) which can be advantageously compared to the latter. An additional advantage could be its expected greater tolerance of wet soils. Nevertheless, its creation appeared to be difficult. So far, the hybrid $L$ decidua $x \angle$ kaempferi seems to be best for reforestation.
\end{abstract}

Larix / larch / tamarack / interspecific hybridization / vegetative propagation / clonal test / stem cutting

Résumé - Comparaison des performances de différents hybrides entre les mélèzes laricins d'Europe et du Japon multipliés végétativement. L'hybridization interspécifique offre à l'améliorateur des perspectives intéressantes pour la création variétale, notamment pour la combinaison de caractères complémentaires favorables et par valorisation de l'hétérosis. Dans cette perspective, plusieurs croisements contrôlés entre le mélèze laricin (Larix laricina) - adapté aux sols hydromorphes - et les mélèzes d'Europe ( $\mathrm{L}$ decidua) et du Japon ( $\mathrm{L}$ kaempferi) ont été tentés, certains avec succès tels le croisement entre le mélèze laricin et le mélèze du Japon et celui de l'hybride triple ( laricina $x(\mathrm{~L}$ decidua $x \mathrm{~L}$ kaempferi)). Bien que possible, l'hybridation avec le mélèze laricin est rendue difficile par de très nombreux problèmes de floraison, entre autres : décalage phénologique, virescence, absence de pollen. Les différents hybrides obtenus ont ensuite été multipliés par bouturage horticole avec des taux d'enracinement élevés et une bonne qualité du système racinaire. En particulier, le bouturage du mélèze laricin et de ses hybrides se révèle encore plus facile que celui des hybrides entre le mélèze d'Europe et du Japon. Les premiers résultats en forêt à 8 ans montrent que malgré une croissance initiale très vigoureuse en termes absolus, ni le mélèze laricin ni son hybride avec le mélèze du Japon ne supportent la comparaison avec l'hybride L decidua $x$ L kaempferi. Seul l'hybride triple apparaît prometteur avec une vigueur et une qualité de forme du fût comparables. Néanmoins, la difficulté de son obtention limite son intérêt pratique à moins qu'il ne se révèle plus tolérant à l'hydromorphie du sol que son parent hybride.

Larix / mélèze / hybridation interspécifique / bouturage / test clonal 


\section{INTRODUCTION}

Among the Larix species, two are of common use for reforestation in western Europe, namely the European larch (Larix decidua Mill) and the Japanese larch (Larix kaempferi (Lamb) Carr = Larix leptolepis (Sieb and Zucc) Gord). A third one, ie the tamarack, a species from North America (Larix laricina (Du Roi) K Koch), has been considered too as a potentially valuable species because of its tolerance to waterlogged soils in its natural range. So far, its plantation has been largely restricted in Europe to botanical gardens and experiments.

As a result of certain biological limitations of each of these species (eg canker sensitivity of Larix decidua, poor stem form and summer drought sensitivity of Larix kaempferi and poor growth and stem form of Larix laricina; Pâques, in preparation), great emphasis has been put on interspecific hybridization in French tree improvement programs.

Interspecific hybridization is used both to develop and combine favourable complementary traits from both parent species as well as to take advantage of hybrid vigour or heterosis.

Hybridization between Larix species is documented by numerous natural and artificial interspecific crosses (Bobrov, 1973, cited in Wright, 1976; Avrov, 1982). No incompatibility barriers, more severe than those observed within a species (corresponding to low filled seed sets (Kosinski, 1987)), seem to exist. Successful crosses have been made even between geographically distant species as reported by Syrach Larsen (1937) and Delevoy (1949).

Among the three Larix species mentioned above, hybridization between the European and the Japanese larches is most commonly used in tree breeaing and its feasibility and interest have been docu- mented for nearly a century (Henry and Flood, 1919).

Hybridization between tamarack and either the European or the Japanese larches seems to be possible as reported by Chowdbury (1931) and Syrack Larsen (1937) for Larix laricina and Larix decidua, and by MacGillivray (1967) for Larix laricina and Larix kaempferi. Nevertheless, as suggested by MacGillivray's (1967) observations, crossing between tamarack and the Japanese larch was quite unsuccessful and no seed could be obtained from reciprocal mating. Moreover, though Avrov (1982) characterizes crossability between tamarack and either the European or the Japanese larches as 'partial', he could get no filled seed from crosses between tamarack and the Japanese larch and no results are presented from crosses including the European larch.

Several matings including the European and Japanese larches on the one hand and the tamarack on the other were attempted in this exploratory study. Objectives were to test their interspecific crossability and if positive, to study the respective hybrids for use in reforestation. In particular, it was interesting to compare their performances with those of pure larch species.

\section{MATERIALS AND METHODS}

\section{Hybridization and material}

Hybridization included crosses between Larix decidua and $L$ kaempferi (coded as 'dec $x$ kae') and its reciprocal: $L$ kaempferi $\times$ L decidua ('kae $x$ dec'). $F_{2}$ hybrids were also attempted by crossing several $F_{1}$ hybrid clones ('(dec $x$ kae) $X$ (dec $\times$ kae)'). Tamarack was involved in three crossings: $L$ laricina $\times L$ decidua ('lar $\times$ dec'), $L$ laricina $\times L$ kaempferi ('lar $\times$ kae') and the 3way hybrid: $L$ laricina $\times$ ( $L$ decidua $\times L$ kaempferi) ('lar X (dec X kae'). 
Hybridization through controlled crossing took place at the INRA Forest Tree Improvement Research Station in Orléans in spring 1979. Hybrids 'lar X (dec X kae)' and '(dec X kae) $X$ (dec $X$ kae)' shared the same father hybrid clone. Different tamarack mother clones were used for obtaining hybrids 'lar $x$ kae' and 'lar $X$ (dec $\times$ kae)'.

Successful hybrids were then field tested and compared to one provenance of Larix kaempferi (coded as 'kae') and to two provenances of Larix laricina ('lar'). No pure European larch was present in the experiment. In addition, two more species were also used as controls of traditional reforestation material, namely Norway spruce (Picea abies (L) Karst, represented by two provenances of southern Poland origin) and Douglas fir (Pseudotsuga menziesii (Mirb) Franco, by one provenance from Arlington, Washington). They will be referred to in tables and figures by 'P ab' and 'P menz' respectively. Provenances of both species have been recommended for reforestation in France because of their outstanding performances. Japanese larch, Norway spruce and Douglas fir are represented by open pollinated material collected in natural forest stands.

A brief description of the material is given in table I. It presents only successful hybrids.

\section{Vegetative propagation}

Prior to field plantation, part of the material under study (ie larch hybrids and tamarack) was vegetatively propagated by stem cuttings and part by seedlings (ie Japanese larch, Norway spruce and Douglas fir). Vegetative propagation had two objectives: first, to multiply poor represented hybrid material, and secondly, to study the feasibility of the technique.

Ortets of the different larch hybrids and of tamarack were selected for total height at 2 years in a progeny test. The proportion of ortets (clones) selected ranged from 1.5 to $35.0 \%$ of each family. Nevertheless, for hybrids 'lar $x$ kae', 'lar $x$ '(dec $x$ kae)' and '(dec $x$ kae) $x$ (dec $x$ kae)', all the seedlings were used as stock plants due to the low number of available seedlings. In total, 184 ortets were finally chosen. Further details about the origin of the material are given in table $\mathrm{I}$.

Ortets were potted in autumn 1981 and forced under greenhouse conditions before propagation.

An average of 30 softwood cuttings per clone (about $10 \mathrm{~cm}$ long) were taken in May 1982 and dipped in a $0.5 \%$ IBA solution including a fungi-

Table I. Larch pure species and hybrids, and control species in experiment (dec $=L$ decidua; kae $: L$ kaempferi; lar = L laricina; $\mathrm{P}$ ab = Picea abies; $\mathrm{P}$ menz = Pseudotsuga menziesii).

\begin{tabular}{|c|c|c|c|c|}
\hline Material code & $\begin{array}{c}\text { Genetic material } \\
\text { and mating system }\end{array}$ & Origin & $\begin{array}{l}\text { Type and year } \\
\text { of propagation }\end{array}$ & $\begin{array}{c}\text { No } \\
\text { of clones }\end{array}$ \\
\hline
\end{tabular}

\begin{tabular}{|c|c|c|c|c|c|}
\hline kae & 1 provenance & OP & Nogana $(\mathrm{J})$ & $\mathrm{S} 83$ & - \\
\hline lar & 2 provenances & $\begin{array}{l}\mathrm{OP} \\
\mathrm{OP}\end{array}$ & $\begin{array}{l}\text { Grafton (NH, USA) } \\
\text { Cass (MN, USA) }\end{array}$ & $\begin{array}{l}\mathrm{C} 82 \\
\mathrm{C} 82\end{array}$ & $\begin{array}{l}20 \\
20\end{array}$ \\
\hline dec $\times$ kae & 14 FS families & $\mathrm{CC}$ & INRA-Orléans (F) & $\mathrm{C} 82$ & 101 \\
\hline kae $\times$ dec & iso progeny & $\mathrm{OP}$ & Farefolden (DK) & $\mathrm{C} 82$ & 25 \\
\hline lar $\times$ kae & 1 FS family & $\mathrm{CC}$ & INAA-Orléans (F) & C82 & 2 \\
\hline $\operatorname{lar} \times(\mathrm{dec} \times \mathrm{kae})$ & 1 FS family & $\mathrm{CC}$ & INRA-Orléans (F) & $\mathrm{C} 82$ & 11 \\
\hline $\begin{array}{l}\text { (dec } \times \text { kae }) \\
X(\text { dec } \times \text { kae })\end{array}$ & 1 FS family & $\mathrm{CC}$ & INRA-Orléans (F) & $\mathrm{C} 82$ & 5 \\
\hline \multirow[t]{2}{*}{$\mathrm{Pab}$} & 2 provenances & $\mathrm{OP}$ & Orawa $(P L)$ & $\mathrm{S} 83$ & - \\
\hline & & $\mathrm{OP}$ & Wisla (PL) & $\mathrm{S} 83$ & - \\
\hline P menz & 1 provenance & $\mathrm{OP}$ & Arlington (WA, USA) & 583 & - \\
\hline
\end{tabular}

FS = Full-sib; SO : seed-orchard; $\mathrm{OP}:$ open pollinated $\mathrm{CC}=$ controlled cross; $\mathrm{S}=$ seedling; $\mathrm{C}=$ cutting. 
cide. They were rooted in a medium mixture (21-3 in volume) of peat, compost and pouzzolane (volcanic ash) under greenhouse conditions. An intermittent mist was used and alternating fungicide treatments were applied as necessary.

Rooted cuttings were then transferred to the INRA nursery in March 1983 for two years before being field planted while the control species ('kae', ' $P$ ab', and 'P menz') were sown in the same nursery in May 1983.

\section{Field experimental design}

Three-year old rooted cuttings and two-year old seedlings were planted together in the Massif Central Mountains during the winter of 1984. Two tests were established: the major one in the State Forest of Eclache (Puy de Dôme, $2^{\circ} 41^{\prime} \mathrm{E}, 45^{\circ} 44^{\prime} \mathrm{N}, 1000 \mathrm{~m}$ ), and a minor one in Peyrat-Le-Château (Haute-Vienne, $1^{\circ} 44^{\prime} \mathrm{E}$, $45^{\circ} 49^{\prime} \mathrm{N}, 450 \mathrm{~m}$ ). Because of low representation of certain hybrids in the latter, only the former will be considered.

Eclache is a good coniferous forest site with a deep brown forest soil and high precipitation well distributed throughout the year (average annual rainfall up to $1000 \mathrm{~mm}$ ). Nevertheless, because of the rather short growing season and particularly windy conditions, the elevation of this site is the upper limit where larch can be planted.

An incomplete, balanced randomized block design was used with 9 blocks, 95 plants per block and two-tree random non-contiguous plots (see Libby and Cockerham, 1980) per genetic entry and per block. Spacing was 3 by 3 meters. No soil preparation and fertilisation were applied prior to plantation.

\section{Measurements}

The percentage of rooted cuttings per clone was estimated and the quality of the root system was assessed according to the following scale: 1 = numerous roots well distributed around the stem base; $2=$ intermediate; $3=$ poor root system with one or two roots and a one-sided distribution; $4=$ no roots.
In addition, the number of rooted cuttings per clone judged to be plantable was based on the frequency of score 1 and 2 for the quality of the root system and on further survival of ramets in the nursery.

First measurements in the field took place in 1989, 8 years after propagation. They concern survival rate $(\% S)$, total height $(H)$, the length of the 1989 height increment (HI) and height growth of the last 4 years, from 1986 to 1989 (HG4)-which corresponds to the growth in the forest after overcoming planting shock. Stem form quality was evaluated. by the frequency of basal sweep (\%BS) and a subjective assessment of stem straightness (SS) on a 5-point scale: class $1=$ severe crookedness with more than two crooks per stem; class $2=$ same as 1 but no more than one or two crooks per stem; class $3=$ light crookedness with more than two crooks per stem; class $4=$ same as 3 but no more than one or two crooks per stem; and, class $5=$ straight stem. The frequency of straight stems (\%SS) for each clone was then estimated from frequency of ramets score for stem straightness greater than 3. Description of stem straightness follows Keiding and Olsen's classification (1965) but in the reverse order.

When possible, an analysis of variance was conducted on individual data following the model:

$$
Y_{i j k l}=\mu+B_{i}+S_{j}+B S_{i j}+C_{k(j)}+\varepsilon_{i j k l}
$$

where

$Y_{i j k l}=l$ th observation of clone $k$ of species ('species' will be used in this paper as a generic term to design both pure larch species and interspecific hybrids) $j$ in block $i$

$\mu=$ general mean

$B_{i}=$ effect of block $i$ (fixed effect),

$S_{j}=$ effect of species $j$ (fixed effect),

$B S_{i j}=$ block $\times$ species interaction,

$C_{k(j)}=$ effect of clone $k$ within species $j$ (random effect),

$\varepsilon_{i j k l}=$ error term.

Prior to analysis, homogeneity of the phenotypic variance-covariance matrices of each genetic entry was tested according to Kullback's test (Legendre and Legendre, 1984) in order to verify whether data from the different genetic en- 
tries could be included in the same analysis or should be analysed separately.

Species means were then compared following Bonferroni's test after adjustment of data for significant block (and interaction) effects if any, and a second analysis of variance on adjusted data. For qualitative variables (eg \%S, \%SS), comparisons between species were based on the original observations according to the 21 or G-test as defined by Sokal and Rohif (1981). It tests the complete independence between two descriptors. Based on contingency tables, 21 is computed following Arbonnier (1966):

$$
\begin{aligned}
2 \mathrm{l} & =\Sigma_{i j} x_{i j} \log x_{i j}+N \log N-\Sigma_{i} X_{i} \log X_{i} \\
& -\Sigma_{j} X_{\cdot j} \log x_{\cdot j}
\end{aligned}
$$

where

$x_{i j}=$ number of observations for genetic entry $i$ and score $j(0 / 1)$,

$X_{i}=$ marginal sum of observations for species $i$

$X_{. j}=$ marginal sum of observations for score $j$,

$k=$ number of species in comparison,

$n=$ number of scores,

$N=$ total number of observations.

$2 \mathrm{l}$ is then compared to $\mathrm{Chi}^{2}$ distribution values with $(k-1)(n-1)$ degrees of freedom. Used in an iterative way, it allows association of the different species in homogeneous groups.

\section{RESULTS}

\section{Hybridization success}

In addition to crosses between European and Japanese larches (88\% of which gave filled seed with rates of filled seed ranging from 16 to $76 \%$ ), those with tamarack were also partly successful. These included crosses between tamarack and the Japanese larch ('lar $x$ kae') and between tamarack and the $F_{1}$ hybrid 'dec $x$ kae'.

The absence of hybrids between tamarack and the European larch is explained by the fact that under Orléans conditions, tamarack flowers earlier than the Euro- pean larch and must therefore be used as a female. Tamarack clones produced no viable pollen and stored pollen of European larch was not available at that time.

Because of a very low reproduction potential of tamarack under Orléans conditions (absence of pollen, numerous proliferated strobili and high rates of empty seed), only one full-sib family per successful tamarack hybrid type ('lar $x$ kae' and 'lar $X$ (dec $x$ kae)') could be produced on two different mother clones. Moreover, the number of viable seedlings obtained up to the nursery stage was low (for 'lar $\mathrm{x}$ kae', 2 seedlings out of 623 seeds and 41 clones; for 'lar $x$ (dec $x$ kae)', 13 seedlings out of 56 seeds and 330 clones). This result confirms Avrov's (1982) and MacGillivray's (1967) observations on the low fertility of this type of crossings. For example, MacGillivray's results on growth performances of tamarack $x$ Japanese larch are based on only four viable seedlings.

\section{Rootability and quality of root system}

More than 5200 cuttings were struck in the rooting medium and nearly $82 \%$ rooted. All 184 tested clones were successfully rooted, with rooting percentages ranging from 9 to 100 .

Rate of success was also very variable from hybrid to hybrid (table II) with the lowest values for 'kae $x$ dec' and '(dec $x$ kae) $X$ (dec $x$ kae)'. 21-test reveals a heterogenous response of rooting ability between species $\left(2 \mathrm{l}=22801>\chi^{2}{ }_{0.95,15 \mathrm{df}=25.0}\right)$ with on one hand 'dec $x$ kae', 'lar' and 'lar $X$ (dec $\times \mathrm{kae}$ )' associated with the highest rooting rates and on the other hand, lar $x$ kae', '(dec $\times$ kae) X (dec $\times$ kae)' and 'kae $x$ dec' with the lowest.

As a whole, $62 \%$ of the rooted cuttings had an excellent root system and more than $88 \%$ were judged satisfactory (scores 
Table II. Average clonal rooting success and quality of root system (standard deviations in brackets).

\begin{tabular}{|c|c|c|c|c|c|c|c|c|c|}
\hline \multirow[t]{2}{*}{ Material } & \multicolumn{2}{|c|}{$\begin{array}{l}\text { No of } \\
\text { clone cuttings }\end{array}$} & \multicolumn{2}{|c|}{$\begin{array}{l}\text { Average clonal } \\
\text { percentage of : }\end{array}$} & \multicolumn{4}{|c|}{$\begin{array}{c}\text { Quality of root system } \\
\text { Percentage of score }\end{array}$} & \multirow{2}{*}{$\begin{array}{l}\text { No of } \\
\text { plantable } \\
\text { clones }\end{array}$} \\
\hline & & & $\begin{array}{l}\text { rooted } \\
\text { cuttings }\end{array}$ & $\begin{array}{l}\text { plantable } \\
\text { cuttings }\end{array}$ & $\begin{array}{c}1 \\
\text { good }\end{array}$ & 2 & 3 & $\begin{array}{c}4 \\
b a d\end{array}$ & \\
\hline lar & 40 & 1193 & $\begin{array}{c}86.7 \\
(15.9)\end{array}$ & $\begin{array}{l}58.8 \\
(21.7)\end{array}$ & $\begin{array}{c}62.9 \\
(16.2)\end{array}$ & $\begin{array}{l}18.6 \\
(9.9)\end{array}$ & $\begin{array}{l}5.3 \\
(7.0)\end{array}$ & $\begin{array}{c}13.3 \\
(15.9)\end{array}$ & 40 \\
\hline dec $\times$ kae & 101 & 2748 & $\begin{array}{c}83.1 \\
(14.3)\end{array}$ & $\begin{array}{l}48.1 \\
(23.1)\end{array}$ & $\begin{array}{c}53.5 \\
(22.1)\end{array}$ & $\begin{array}{c}21.5 \\
(13.7)\end{array}$ & $\begin{array}{c}10.7 \\
(12.1)\end{array}$ & $\begin{array}{c}14.4 \\
(11.6)\end{array}$ & 100 \\
\hline kae $\times$ dec & 25 & 850 & $\begin{array}{c}61.8 \\
(28.8)\end{array}$ & $\begin{array}{c}13.7 \\
(13.1)\end{array}$ & $\begin{array}{l}24.2 \\
(22.5)\end{array}$ & $\begin{array}{c}28.3 \\
(19.3)\end{array}$ & $\begin{array}{c}9.3 \\
(8.3)\end{array}$ & $\begin{array}{c}38.2 \\
(28.8)\end{array}$ & 19 \\
\hline lar x kae & 2 & 55 & $\begin{array}{l}75.3 \\
(12.3)\end{array}$ & $\begin{array}{l}56.7 \\
(4.7)\end{array}$ & $\begin{array}{c}66.3 \\
(13.7)\end{array}$ & $\begin{array}{c}9.0 \\
(1.4)\end{array}$ & $\begin{array}{c}0.0 \\
(0.0)\end{array}$ & $\begin{array}{c}24.7 \\
(12.3)\end{array}$ & 2 \\
\hline $\operatorname{lar} X($ dec $\times$ kae $)$ & 11 & 287 & $\begin{array}{c}81.5 \\
(17.4)\end{array}$ & $\begin{array}{c}60.7 \\
(24.6)\end{array}$ & $\begin{array}{c}62.6 \\
(28.9)\end{array}$ & $\begin{array}{c}15.0 \\
(14.6)\end{array}$ & $\begin{array}{c}3.8 \\
(6.0)\end{array}$ & $\begin{array}{c}18.5 \\
(17.4)\end{array}$ & 10 \\
\hline $\begin{array}{l}\text { (dec } \times \text { kae }) \\
\text { X (dec } \times \text { kae })\end{array}$ & 5 & 85 & $\begin{array}{c}66.6 \\
(18.3)\end{array}$ & $\begin{array}{c}4.8 \\
(5.0)\end{array}$ & $\begin{array}{c}22.4 \\
(26.9)\end{array}$ & $\begin{array}{c}17.8 \\
(15.8)\end{array}$ & $\begin{array}{c}28.9 \\
(26.9)\end{array}$ & $\begin{array}{c}30.9 \\
(25.4)\end{array}$ & 3 \\
\hline Global & 184 & 5218 & 81.7 & 46.8 & 51.0 & 21.6 & 9.3 & 18.1 & 174 \\
\hline
\end{tabular}

$1+2)$. Nevertheless, hybrids responded very differently $\left(2 \mathrm{l}=471.2>\mathrm{Chi}^{2} 0.95,15 \mathrm{df}\right)$. Hybrids 'lar $x$ kae' and 'lar X (dec $x$ kae)' with the best root system quality could be grouped together, followed then by 4 other groups: 'lar'; 'dec $x$ kae'; 'kae $x$ dec'; and ' (dec $\times$ kae) X (dec $\times$ kae)'.

At 3 years, before outplanting, the total proportion of plantable cuttings went down to $57 \%$ (or less than $47 \%$ of the initial total number of cuttings inserted). This severe reduction due to absence of rooting or poor root system and mortality in the nursery affected all species; the worst results (up to $80 \%$ loss) were observed for hybrids 'kae $\mathrm{x}$ dec' and '(dec $\mathrm{x}$ kae) $\mathrm{X}$ (dec $\mathrm{X}$ kae)'. For the others, nearly $50 \%$ of the cuttings could be planted in the forest. Three homogeneous groups were constituted: they included from best to worst tamarack and its hybrids ('lar X (dec x kae)', 'lar' and 'lar $x$ kae'); 'dec $x$ kae'; and '(dec $x$ kae) $X$ (dec $x$ kae)' and 'kae $x$ dec'. Ten clones had disappeared at that stage, six of which were from the hybrid 'kae $x$ dec'.

\section{Field performance}

Homogeneity of the phenotypic variancecovariance matrices for the seven larch entries for total height and stem straightness at 8 years was accepted: $\mathrm{Chi}^{2} \mathrm{~K}=4.315<$ $\mathrm{Chi}^{2}{ }_{0.95,} 18 \mathrm{df}$ ). Data of all the larch species were then included in the analysis of variance, except those of the Japanese larch propagated by seedlings.

Survival rates at 8 years (or 7 for seedlings) ranged from 69 and $97 \%$ for cuttings (table III) and reached nearly $92 \%$ for the Japanese larch seedlings. 2l-test was significant at $\alpha=0.05\left(2 \mathrm{l}=85.2>\chi^{2} 0.95 .10 \mathrm{df}\right)$. Three homogeneous groups could be defined, with hybrid 'lar X (dec $x$ kae)' in the first group; in the second, Japanese larch seedlings, '(dec $x$ kae) X (dec $\times$ kae)', 'lar $\times$ 
Table Ill. Average survival (\%S), total height at 8 years $(\mathrm{H}), 1989$ height increment $(\mathrm{HI})$, height growth from 1986 to 1989 (HG4), \% basal sweep (\%BS), stem straightness (SS) and percentage of straight stem (\%SS) at 8 years. Coefficients of variation are given in brackets.

\begin{tabular}{|c|c|c|c|c|c|c|c|c|}
\hline Material & $n_{i}$ & $\% S$ & $\begin{array}{c}H \\
(\mathrm{~cm})\end{array}$ & $\begin{array}{c}\mathrm{HI} \\
(\mathrm{cm})\end{array}$ & $\begin{array}{l}H G 4 \\
(\mathrm{~cm})\end{array}$ & $\begin{array}{l}\% B S \\
(0-1)\end{array}$ & $\begin{array}{c}\text { SS } \\
(1-5)\end{array}$ & $\begin{array}{c}\% S S \\
(S S>3)\end{array}$ \\
\hline kae & 36 & 91.7 & $\begin{array}{c}307.5 \\
(17.1)\end{array}$ & $\begin{array}{c}68.7 \\
(26.9)\end{array}$ & $\begin{array}{c}219.6 \\
(17.0)\end{array}$ & 33.3 & $\begin{array}{l}2.58 \\
(36.4)\end{array}$ & 12.1 \\
\hline lar & 114 & 71.1 & $\begin{array}{c}266.6 \\
(19.8)\end{array}$ & $\begin{array}{c}63.7 \\
(23.0)\end{array}$ & $\begin{array}{l}180.6 \\
(21.4)\end{array}$ & 28.2 & $\begin{array}{l}2.35 \\
(37.4)\end{array}$ & 4.2 \\
\hline dec $\times$ kae & 1230 & 87.4 & $\begin{array}{c}383.9 \\
(16.0)\end{array}$ & $\begin{array}{c}93.8 \\
(19.2)\end{array}$ & $\begin{array}{c}267.4 \\
(15.7)\end{array}$ & 42.8 & $\begin{array}{l}3.17 \\
(30.9)\end{array}$ & 33.1 \\
\hline kae $\times$ dec & 80 & 68.8 & $\begin{array}{c}329.5 \\
(19.8)\end{array}$ & $\begin{array}{c}76.4 \\
(27.8)\end{array}$ & $\begin{array}{l}231.0 \\
(20.1)\end{array}$ & 42.3 & $\begin{array}{c}3.29 \\
(28.5)\end{array}$ & 36.5 \\
\hline lar $x$ kae & 8 & 87.5 & $\begin{array}{c}259.6 \\
(26.5)\end{array}$ & $\begin{array}{c}57.1 \\
(48.7)\end{array}$ & $\begin{array}{l}180.6 \\
(29.3)\end{array}$ & 0.0 & $\begin{array}{r}2.29 \\
(41.6)\end{array}$ & 0.0 \\
\hline $\operatorname{lar} \times($ dec $\times k a e)$ & 66 & 97.0 & $\begin{array}{c}337.7 \\
(18.7)\end{array}$ & $\begin{array}{r}78.6 \\
(26.6)\end{array}$ & $\begin{array}{l}22^{r} \\
(20.1)\end{array}$ & 11.1 & $\begin{array}{l}3.17 \\
(28.6)\end{array}$ & 34.9 \\
\hline $\begin{array}{l}\text { (dec } \times \text { kae) } \\
\times \text { (dec } \times \text { kae })\end{array}$ & 8 & 87.5 & $\begin{array}{c}309.3 \\
(14.1)\end{array}$ & $\begin{array}{r}73.0 \\
(20.4)\end{array}$ & $\begin{array}{l}202.3 \\
(14.3)\end{array}$ & 33.3 & $\begin{array}{c}3.33 \\
(15.5)\end{array}$ & 33.3 \\
\hline$P a b$ & 78 & 59.0 & $\begin{array}{c}184.7 \\
(23.4)\end{array}$ & $\begin{array}{r}49.1 \\
(29.0)\end{array}$ & $\begin{array}{l}123.8 \\
(31.9)\end{array}$ & 0.0 & $\begin{array}{r}4.0 \\
(0.0)\end{array}$ & 100.0 \\
\hline$P$ menz & 36 & 63.9 & $\begin{array}{c}276.1 \\
(17.3)\end{array}$ & $\begin{array}{r}67.5 \\
(32.3)\end{array}$ & $\begin{array}{l}190.4 \\
(25.9)\end{array}$ & 0.0 & $\begin{array}{r}4.0 \\
(0.0)\end{array}$ & 100.0 \\
\hline
\end{tabular}

kae' and 'dec $x$ kae'; and in the third group, tamarack 'lar', 'kae $x$ dec', Douglas fir and Norway spruce. Survival of Norway spruce was particularly poor.

As reported in table III, height growth in 1989 (HI) was vigorous for all entries. Among them, hybrids 'dec $x$ kae', 'lar $X$ (dec $x$ kae)' and 'kae $x$ dec' were the most noticeable with a shoot length of $93.8,78.6$ and $76.4 \mathrm{~cm}$ respectively. Analysis of variance of vigour traits ( $H$ and $H G 4)$ showed highly significant effects $(\alpha=0.001)$ of the three main factors: block, species andclone within species with no significant interaction between blocks and species (table IV). Data were adjusted for block effects.

Figure 1 summarizes results of Bonferroni's test of comparison of means for total height at 8 years $(H)$. The hybrid 'dec $x$ kae' clearly gave the best results. It surpassed Norway spruce ('P ab') by $108 \%$, tamarack ('lar') by $44 \%$, Douglas fir ('P menz') by $39 \%$ and the Japanese larch ('kae') by $25 \%$. It was significantly superior too over the other hybrids with values ranging from $48 \%$ over 'lar $\times$ kae' down to $14 \%$ over 'lar $X$ (dec $\times$ kae)'. Results are mostly similar for HG4 but with superiority of hybrid 'dec $x$ kae' over the other genetic entries even more important. As a comparison, in the minor test of Peyrat-LeChâteau, the hybrid 'dec $\times$ kae' reached $413 \mathrm{~cm}$ for total height at the same age; it surpassed by only $9 \%$ hybrid 'lar $X$ (dec $x$ kae)' and by $72 \%$ tamarack ('lar').

Total height growth development over time from 1986 to 1989 is presented in fi- 
Table IV. ANOVA for total height at 8 years (H), growth height from 1986-1989 (HG4), 1989 height increment and stem straightness (SS).

\begin{tabular}{|c|c|c|c|c|c|c|c|c|c|}
\hline \multirow[b]{2}{*}{ Source } & \multirow[b]{2}{*}{$D F$} & \multicolumn{2}{|c|}{$H$} & \multicolumn{2}{|c|}{ HG4 } & \multicolumn{2}{|c|}{$H I$} & \multicolumn{2}{|c|}{ SS } \\
\hline & & $M S$ & $F$ & $M S$ & $F$ & $M S$ & $F$ & $M S$ & $F$ \\
\hline $\begin{array}{l}\text { Block } \\
\text { Species } \\
\text { Block x sp } \\
\text { Clones (sp) } \\
\text { Error }\end{array}$ & $\begin{array}{r}8 \\
5 \\
29 \\
118 \\
1094\end{array}$ & $\begin{array}{r}45031.75 \\
243796.66 \\
2606.90 \\
9239.90 \\
2843.92\end{array}$ & $\begin{array}{c}15.834^{\mathrm{c}} \\
26.385^{\mathrm{c}} \\
0.917^{\mathrm{ns}} \\
3.249^{\mathrm{c}}\end{array}$ & $\begin{array}{r}22802.32 \\
137074.41 \\
1438.64 \\
3798.27 \\
1380.15\end{array}$ & $\begin{array}{c}16.522^{\mathrm{c}} \\
36.089^{\mathrm{c}} \\
1.042^{\mathrm{ns}} \\
2.752^{\mathrm{c}}\end{array}$ & $\begin{array}{r}1969.25 \\
9417.14 \\
207.96 \\
545.31 \\
263.23\end{array}$ & $\begin{array}{c}7.481^{c} \\
17.269^{c} \\
0.807^{n s} \\
7.282^{c}\end{array}$ & $\begin{array}{r}1.75 \\
10.43 \\
0.47 \\
4.26 \\
0.59\end{array}$ & $\begin{array}{l}2.989^{b} \\
2.449^{a} \\
0.806^{\text {ns }} \\
7.260 c\end{array}$ \\
\hline
\end{tabular}

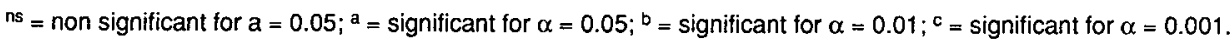

gure 2. Except for the Japanese larch ('kae') and the hybrids 'kae $x$ dec' and 'lar $x$ kae', superiority of the hybrid 'dec $x$ kae' over the other species tended to increase. According to their growth curve pattern, the species might be associated in three groups corresponding to fast, intermediate and slow growing material. Respectively, these would include 'dec $x$ kae'; 'lar X (dec $x$ kae)', 'kae $x$ dec', '(dec $x$ kae) $X$ (dec $x$ kae)' and 'kae'; and finally 'lar' and 'lar $x$ kae'.

Highly significant differences (at $\alpha=$ 0.001 ) are noted too between species for stem straightness (SS) at 8 years as well as between blocks (table IV). Two entries including the tamarack ('lar') and its $F_{1}$ hybrid with the Japanese larch ('lar $x$ kae') were characterized by severe crook (table III) and were significantly different (at $\alpha=$ 0.01) from the other entries.

As well, for the frequency of basal sweep (\%BS) and the rate of straight stems (\%SS), the material responded differently $\left(2 \mathrm{I}=95.8>\mathrm{Chi}^{2} 0.95,10 \mathrm{df}\right.$ for \%BS and $2 \mathrm{l}=195.6>\mathrm{Chi}^{2} 0.95,10 \mathrm{df}$ for \%SS). The material could be associated in three homogeneous groups. They included from best to worst: Norway spruce ( $P$ ab) and Douglas fir ( $P$ menz); 'lar $x$ kae' and 'lar X (dec x kae)'; 'lar', 'kae', 'kae x dec' and 'dec $x$ kae' for basal sweep, with values ranging from no defect for the species used as control up to more than $42 \%$ for the hybrid 'dec $x$ kae'. For frequency of straight stems (\%SS), group 1 included Norway spruce (P $\mathrm{ab})$ and Douglas fir (P menz); group 2 'kae $x$ dec', 'lar X (dec x kae)' and 'dec x kae'; and group 3 'kae', '(dec $x$ kae) $X$ (dec $x$ kae)', 'lar' and 'lar $x$ kae'. \%SS ranged from no defect for the control species up to $100 \%$ for the hybrid 'lar $x$ kae'. ' $x$ kae') was quite severely affected with nearly two-thirds of crooked stems (table III).

\section{DISCUSSION AND CONCLUSION}

Hybridization including tamarack is reported here for the first time in France and the test at Eclache is the first opportunity to observe tamarack hybrids performance in the field.

Hybridization between European and Japanese larches does not raise any particular problems besides those well known to larch breeders, namely the low set of filled seed per cone which is observed in both natural and artificial crosses (Kosins- 
Total Height

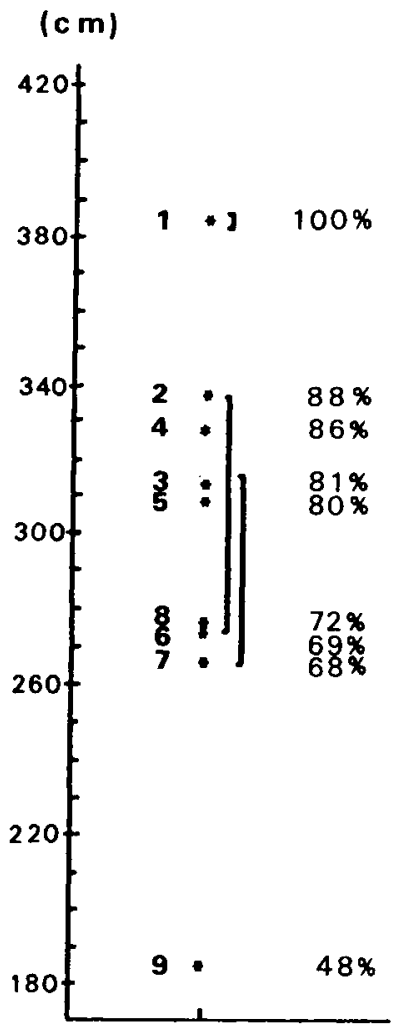

Fig 1. Comparison of species mean performances for total height at 8 years (Bonferroni test, at $\alpha=5 \%)$. Performances are expressed in percentage of hybrid 'dec $\times$ kae'. ( $1=$ dec $\times$ kae / $2=\operatorname{lar} X(\operatorname{dec} \times \mathrm{kae}) / 3=(\operatorname{dec} \times \mathrm{kae}) X(\mathrm{dec} \times$ kae) $/ 4=$ kae $x \operatorname{dec} / 5=$ kae $/ 6=\operatorname{lar} / 7=\operatorname{lar} x$ kae $/ 8=\mathrm{P}$ menz $/ 9=\mathrm{P}$ ab) .

ki, 1987). Hybridization using tamarack proved to be possible but difficult under Orléans climatic conditions. The limited success noted in this study may mostly be due to problems connected with flower development (proliferated female strobili, maturation failure of male strobili with resulting lack of pollen production, non-matching

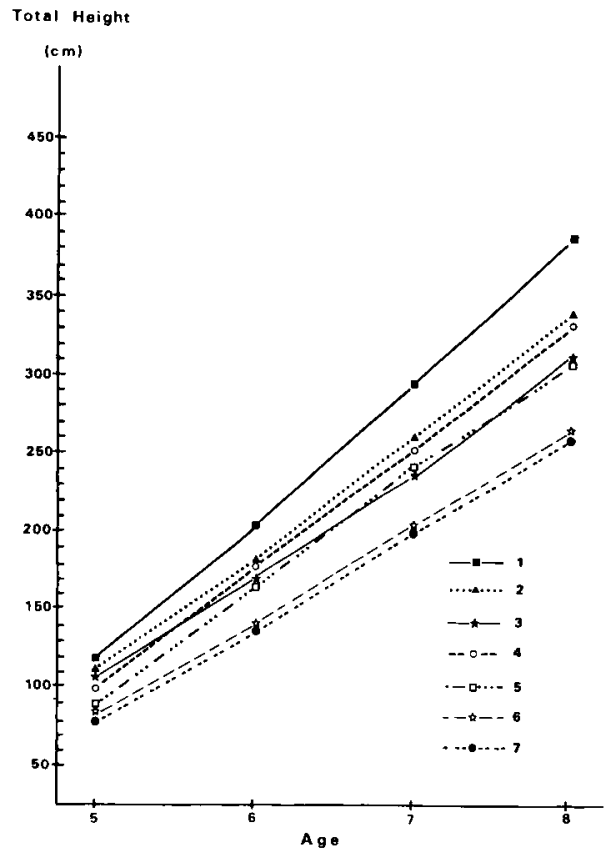

Fig 2. Total height growth development over time. $(1=$ dec $\times$ kae $/ 2=\operatorname{lar} X($ dec $\times$ kae $) / 3=$ (dec $\times$ kae) $\times($ dec $\times \mathrm{kae}) / 4=\mathrm{kae} \times \mathrm{dec} / 5=$ kae $/ 6=\operatorname{lar} / 7$ = lar $\times$ kae) .

phenology with other species (Japanese (arch)).

Vegetative propagation was successful for most of the hybrids but clonal variation was substantial. Such a high rate of rooting with young plants is not unusual (Mason, 1989). The low performance during the propagation phase of two hybrids 'kae $x$ dec' and '(dec $\times$ kae) $X$ (dec $x$ kae)' for both rootability and their root system quality cannot be attributed to vigour of the donor plants; they were as vigorous as those of other species. Possible explanations could be either the age of the donor plants for hybrid 'kae $x$ dec' (one year older than other hybrid stocks) or the genetic na- 
ture of the material or both. Hybrid 'kae $x$ dec' clones were in fact selected in a single progeny from open pollinated hybridization in a seed orchard while hybrid '(dec $\times$ kae) X (dec $\times$ kae)' clones were selected in a single $F_{2}$ full-sib family, the parents of which were full sibs. In both cases, inbreeding may have taken place and this could have serious depression effects, as expected on larch (Dieckert, 1964). No abnormality of growth (growth depression, abnormal branchiness) was nevertheless detected at the time of ortet selection.

Considering the traits related to vegetative propagation, tamarack as well as its hybrids perform better than the other hybrids, 'dec $x$ kae' included. This is particularly true for the quality of the root system (table II).

In the field test, no serious adaptation problems have been noted as survival up to 8 years is judged satisfactory, except for tamarack with nearly $30 \%$ mortality. Similar results were observed for seedlings of the same two tamarack provenances used in this study (and others from the same latitude) in an arboretum located in the Massif Central Mountains (Margeride, Lozère, elevation: $1470 \mathrm{~m}$ ) (Imbert, 1988). Although the latitudes of origin of the tested provenances are similar to those of the test sites, the local weather conditions are severe (windy) and a better choice of provenances from higher latitudes and less oceanic influenced zones might be recommended. In any case, larches showed a much higher survival rate than Norway spruce and Douglas fir. This is not surprising for this Douglas fir provenance (Arlington) which may be at its ecological limit here. For Norway spruce which is traditionally used in this region, no obvious explanation can be given.

With regard to growth and vigour (table III), neither tamarack nor its hybrids ex- ceeded performances of better known hybrids ('dec $\times$ kae' or its reciprocal) with the exception of hybrid 'lar X (dec $x$ kae)'. Tamarack was very poor but in any case, its height growth was faster than that of Norway spruce. The three-way hybrid 'lar $\mathrm{X}$ (dec $\times$ kae)' was vigorous with performances intermediate (and significantly different) to those of its parental species ('lar' and 'dec $x$ kae'): $-13,7 \%$ compared to 'dec $x$ kae', $+26.7 \%$ with respect to 'lar' for total height at 8 years. In contrast, the single hybrid 'lar $x$ kae' performances were even lower (but not significantly different at $\alpha=$ 0.01 ) than those of its poorer parent species ('lar'). MacGillivray (1967) observed a much more favourable performance of that hybrid in south-central New Brunswick where it was $48.0 \%$ and $57.4 \%$ taller respectively than $L$ laricina and $L$ kaempferi at 7 years. But his observations were based on only four seedlings.

The hybrid between $L$ decidua and $L$ kaempferi is known for its remarkable vigour (Pâques, 1989) which is confirmed by the present study in rather severe ecological conditions. As a comparison, at two other sites in somehow milder conditions of the western range of the Massif Central Mountains, total height at the same age and for a similar genetic material exceeded by 76 and $27 \%$ respectively total height recorded on the site of Eclache.

The $F_{2}$ hybrid '(dec $\times$ kae) $\times$ (dec $\times$ kae)' had an intermediate growth. Its success seems highly dependent on the coancestry level of its $F_{1}$ parent clones (Dietze, 1974).

If tamarack and its hybrids presented few basal sweep defects as compared to $L$ decidua $x L$ kaempferi, they were on average affected by serious stem form problems with a much higher frequency of crooked stems and more severe defects. Hybrid 'lar X (dec $x$ kae)' was once again an exception as its stem form quality was very close to that of 'dec $x$ kae' (table III). 
Stem form is nevertheless a general problem in larch breeding (Keiding and Olsen, 1965) and as shown in table III, no hybrid or pure species is really free from this defect, the frequency of which goes up to $50 \%$ even for the best tested material. This condition is not restricted to vegetatively propagated material (Dietze, 1974). Moreover, straightness and vigour have been observed in many of our experiments to be negatively correlated and for certain hybrids, correlations are significantly different from zero (for $\alpha=0.05$ ) (table V). Fortunately, a rather broad variability exists for this trait at the various levels (ramet (table III), clone, family and population). Therefore, further selection will certainly improve this trait.

Tamarack is a poorly known species in France. These first results from experiments indicate that choice of provenances and proper sites for reforestation under French conditions is important (imbert, 1988; Pâques, in preparation). Although vegetative propagation and adaptation do not seem to be serious problems in this experiment, field performance for the most important traits (vigour and stem form) of both tamarack and its hybrids was never superior to better known hybrids between the European and Japanese larches (even to the second generation hybrid '( $\mathrm{dec} x$ kae) $X$ (dec $x$ kae)'). One major exception is for the 3-way hybrid ( $L$ laricina X ( $L$ de- cidua $\times$ L kaempferi)) which combines excellent adaptability, fast growth (second to $L$ decidua $\times \quad L$ kaempfer $)$ and good stem form (\% BS, SS, \%SS). Similar observations both on the remaining trees in the minor test site of Peyrat-Le-Château and in Orléans clone collection confirm its quality.

Due to the low number of entries (ramets, clones and families) for some hybrids, precise comparison of material was not always possible. In particular, it is difficult to detect whether the observed performance differences are the result either of clone sampling or of the species themselves. Testing on more sites and of other clones from a wider range of hybrid families should be undertaken to confirm these early results and to give indications about the interest of tamarack hybrids over $L$ decidua $<$ kaempferi.

But in any case, the difficulty - confirmed by later attempts - to obtain hybrids using tamarack either as female or as male under Orléans conditions is a major limiting factor whatever the interest of some of its hybrids.

Transfer of favourable traits from one species to another through interspecific hybridization is of major interest in larch breeding as the species commonly used, seem complementary for a number of characteristics (eg canker resistance, stem form). In particular, it is important to check if the tamarack tolerance to waterlogged

Table V. Phenotypic correlations between total height $(H)$ and stem straightness (SS) at 8 years (based on individual observations within species).

\begin{tabular}{|c|c|c|c|c|c|c|c|}
\hline Material & kae & lar & (dec $\times k a e)$ & $(k a e \times d e c)$ & (lar $\times$ kae) & $\begin{array}{c}\operatorname{lar} X \\
(\operatorname{dec} \times k a e)\end{array}$ & $\begin{array}{c}\text { (dec } \times \text { kae) } \times \\
(\text { dec } \times \text { kae })\end{array}$ \\
\hline$r_{\mathrm{p}}$ & $-0.115^{\text {ns }}$ & $-0.245^{*}$ & $-0.228^{c}$ & $0.031^{n s}$ & - & $-0.108^{\text {ns }}$ & - \\
\hline
\end{tabular}

- = Neglected because of too few common observations; see table IV for significance levels. 
soils might be transferred to other larch species through hybridization. Further research work with tamarack will be oriented in this direction.

\section{ACKNOWLEDGMENTS}

The technical assistance of $P$ Legroux and $M$ Faucher for data collection and the help of $\mathrm{CH}$ Schneider for statistical analysis were greatly appreciated.

\section{REFERENCES}

Arbonnier P (1966) L'analyse de l'information. Aperçu theorique et application à la loi multinomiale. Ann Sci For 23, 950-1017

Avrov FD (1982) Crossability of various larch species at a collection-parent plantation in southern Siberia. Lesovedenie 5, 23-29 (in Russian)

Bobrov EG (1973) Introgressive Hybridisation. Sippenbildung und Vegetationsänderung. Fed Rep 84, 273-294

Chowdbury KA (1931) Anatomical studies of the wood of Larix eurolepis. J For 29, 797

Delevoy G (1949) Larix eurolepis (Henry A, Flood M, eds). Bull Soc Centr For Belg 1949, 178-194

Dieckert H (1964) Einige Untersuchungen zur Selbsterilität Und Inzucht bei Fichte und Lärche. Silvae Genet 13, 77-86

Dietze W (1974) Beurteilung von züchterischen Möglichkeiten zur Verbesserung quantitativer und qualitativer Eigenschaften bei europäischer Lärche (Larix decidua Mill). Dissertation, Forstwissensschftl. Fakultät, Univ Munich
Henry A, Flood MG (1919) The history of the Dunkeld larch. Proc $A$ ir Acad Sec B 35

Keiding $H$, Olsen HC (1965) Assessment of stem form in clones and progenies of larch. Silvae Genet 14, 115-122

Kosinski G (1987) Empty seөd production in European larch (Larix decidua). For Ecol Manag $19,241-246$

Imbert P (1988) Choix des Espèces de Reboisement en Haute-Margeride. Premier bilan de I'Arboretum Curie (Lozere-Col des 3 Sceurs, Alt $1470 \mathrm{~m}$ ). INRA-Orléans, document $n^{\circ} 397$

Legendre L, Legendre P (1984) Écologie Numérique. 2. La Structure des Données Écologiques. Masson, Québec, 182-183, 2nd edn

Libby WJ, Cockerham CC (1980) Random noncontiguous plots in interlocking field layouts. Silvae Genet 29, 183-190

MacGillivray HG (1967) Hybrid between tamarack and Japanese larch appears promising in south central New Brunswick. Res Notes Dep For Can 23, 2-3

Mason WL (1989) Vegetative propagation of hybrid larch (Larix $x$ eurolepis Henry) using winter cuttings. Forestry 62 (suppl), 189-198

Pâques LE (1989) A critical review of larch hybridization and its incidence on breeding strategies. Ann Sci For 46, 141-153

Pâques LE, Cornu D (1991) Effect of vegetative propagation on field performance up to age 8 of hybrid larch (Larix $x$ eurolepis) clones. Ann Sci For 48, 469-482

Sokal RR, Rohlf FJ (1981) Biometry - The Principles and Practice of Statistics in Biological Research. Freeman, San Francisco, 859, 2nd edn

Syrach Larsen C (1937) The Employment of Species, Types and Individuals in Forestry. Copenhagen, 1937

Wright JW (1976) Introduction to Forest Genetics. Academic Press, New York, 322-323 